\title{
Muscle Thiobarbituric Acid Reactive Substance of the Atlantic Herring (Clupea harengus) in Marinades Collected in the Market Network
}

\author{
Alena Halamíčková, Ladislav Malota \\ Department of Biochemistry, Chemistry and Biophysics, Faculty of Veterinary Hygiene and Ecology, \\ University of Veterinary and Pharmaceutical Sciences Brno, Czech Republic
}

Received November 28, 2008

Accepted December 3, 2009

\begin{abstract}
Fish fat belongs to highly specific nutritious elements especially due to its high content of polyunsaturated fatty acids. The aim of the present study was to determine the content of 2 -thiobarbituric acid reactive substances in over-the-counter cold and warm marinades in which the base fish material consists of the Atlantic herring (Clupea harengus).

Fifty six marinated fish products stored at refrigeration temperatures were analyzed before their expiration date. Their fat content was determined by means of the Soxhlet method and the TBARS validated fluorimetric micromethod.

Lowest TBARS values were characteristic of warm baked marinades $(1.17 \pm 0.40 \mathrm{mg} \mathrm{MDA} /$ $\mathrm{kg}$ muscle) and in case of cold marinades for the rolled herring fillets with pepper $(5.03 \pm 0.54 \mathrm{mg}$ MDA $/ \mathrm{kg}$ muscle) whereas the highest TBARS values were observed in warm cooked marinades $(16.48 \pm 4.22 \mathrm{mg} \mathrm{MDA} / \mathrm{kg}$ muscle) and in roll mops sold over the counter $(7.61 \pm 3.87 \mathrm{mg}$ MDA $/ \mathrm{kg}$ muscle). The results showed that fat content is not always critical for herring TBARS determination in marinades.

For the consumer safety it is essential to pay attention to cold marinades in brine sold over the counter and baked marinades in aspic before their expiration date.
\end{abstract}

Marinated fish, fat, lipid oxidation, TBARS, baked and cold marinade

Fish fat belongs to highly specific nutritious elements especially due to its high content of polyunsaturated fatty acids which play an important role in prevention of cardiovascular and other diseases. Sea fish present the main source of these acids. The most serious cause of a decrease in the nutritive value of fat in all fish species is oxidation occurring in the organism in vivo. Post mortem oxidation is accelerated due to new pro-oxidation factors, such as the presence of atmospheric oxygen and various technological procedures or storage conditions (Undeland et al. 1998; Undeland and Lingnert 1999).

Methods detecting the present fatty acids or oxidation products are generally used for lipid oxidation determination. One of the frequent methods is determination of TBARS, the 2-thiobarbituric acid reactive substances (Decker et al. 2005; Guillén-Sans and Gurmán-Chozas 1998). The method determines aldehydes formed by degradation of hydroperoxide, including malonaldehyde (MDA) which is used as a standard. Experimental animal studies and biochemical research lend support to the hypothesis that lipid oxidation products ingested with food present a health risk (Esterbauer 1993).

The aim of the experiment was to determine TBARS using fluorimetric micromethod in selected cold and warm market marinades before their expiration date, in which the fish material is of the Atlantic herring (Clupea harengus).

\section{Materials and Methods}

The following consumer packages of marinades available on the market were purchased for the purpose of the analysis:

A, cold marinades: Rolled herring fillets with pepper - 10 packages: marinated herring $120 \mathrm{~g}$, oil, salt $5 \%$ max, acetic acid, sugar, saccharine, cabbage, onion, carrot, gherkin, pepper $0.05 \%$, potassium sorbate, sodium benzoate. 
$\mathrm{B}$, cold marinades: Rolled herring fillets with garlic - 10 packages: Baltic herring $120 \mathrm{~g}$, garlic, vinegar, oil, salt $3.4 \%$ max

C, cold marinades: Tender rolled herring fillets - 10 packages: marinated herring $80 \%$, vegetable oil, salt $5 \%$ max, fermentative vinegar, sugar potassium sorbate, sodium benzoate.

D, cold marinades: Roll mops - 10 pieces from different packages: pickled herring fillets $50 \%$ min, pickled onion, sterilized cabbage, sterilized gherkin, sterilized carrot, souse (vinegar, sugar, salt, citric acid, potassium sorbate, sodium benzoate).

E, warm (cooked) marinades: Herring fillets in aspic -8 packages: marinated herring fillets (herring fillets, cauliflower, peas, carrot), aspic 47\% (water, vinegar, salt, spices, saccharine).

F, warm (baked) marinades: Baked herring cuts in brine -8 packages: roast herring $60 \%$ (herring cuts), wheat flour, vegetable oil, souse $40 \%$ (water, vinegar, salt, spices, saccharine).

Consumer packaging of each tested product type varied by expiration date (40 days, in group D marinades 7 days) before which chemical analysis was performed. The fat was determined using the Soxhlet extraction method (Davídek et al. 1981). The calculation was made from the residue between dry matter and fat-free dry matter. For TBARS determination the validated fluorimetric micromethod was used according to Tanizawa et al. (1981). Relative fluorescence was measured using the SFM - 25, KONTROL Instrument, Zürich spectrofluorometre (excitation $515 \mathrm{~nm}$, emission $553 \mathrm{~nm}$ ). The TBARS contents were calculated in $\mathrm{mg} \mathrm{MDA} / \mathrm{kg}$ of muscle in accordance with the calibrating line equation where $y=28.605 x+2.41(r=0.9997)$ and the conversion factor for fish meat according to supernatant liquor volume.

Significance $(p<0.05)$ for fat contents among different marinade types, TBARS in mg MDA/kg of muscle and TBARS in mmol MDA/kg of fat was determined by analysis of variance, and the differences between pairs of various marinade types by Student's $t$-test. The dependence of TBARS on fat contents was tested by Pearson correlation coefficient.

\section{Results}

Table 1 shows totals of measured fat values and TBARS related to a muscle unit and fat unit in six marinade types all of which vary in the production process or in qualitative and quantitative material representation.

Table 1. Fat and TBARS contents in muscle of herrings from cold and warm marinades

\begin{tabular}{|l|c|c|c|c|c|}
\hline Product & $\begin{array}{c}\text { Fat } \\
(\mathrm{g} / \mathrm{100} \text { g of } \\
\text { muscle })\end{array}$ & $\begin{array}{c}\text { TBARS } \\
(\mathrm{mg} \mathrm{MDA} / \mathrm{kg} \text { of } \\
\text { muscle })\end{array}$ & $\mathrm{r}$ & $\begin{array}{c}\text { Significance } \\
\mathrm{r}\end{array}$ & $\begin{array}{c}\text { TBARS } \\
\text { (mmol } \\
\text { MDA/kg fat) }\end{array}$ \\
\hline $\begin{array}{l}\text { A: Rolled herring fillets } \\
\text { with pepper in oil }\end{array}$ & $\begin{array}{c}* \mathrm{~B}, \mathrm{C}, \mathrm{D} \\
12.19 \pm 1.36\end{array}$ & $\begin{array}{c}* \mathrm{~B}, \mathrm{C}, \mathrm{E}, \mathrm{F} \\
5.03 \pm 0.54\end{array}$ & 0.2986 & $p>0.05$ & $\begin{array}{c}* \mathrm{~B}, \mathrm{C}, \mathrm{D}, \mathrm{E}, \mathrm{F} \\
0.58 \pm 0.08\end{array}$ \\
\hline $\begin{array}{l}\text { B: Rolled herring fillets } \\
\text { with garlic in oil }\end{array}$ & $\begin{array}{c}* \mathrm{~A}, \mathrm{E}, \mathrm{F} \\
9.20 \pm 0.98\end{array}$ & $\begin{array}{c}* \mathrm{~A}, \mathrm{E}, \mathrm{F} \\
6.05 \pm 0.91\end{array}$ & 0.2870 & $p>0.05$ & $\begin{array}{c}* \mathrm{~A}, \mathrm{D}, \mathrm{E}, \mathrm{F} \\
0.92 \pm 0.13\end{array}$ \\
\hline $\begin{array}{l}\text { C: } \text { Tender rolled herring } \\
\text { fillets in oil }\end{array}$ & $\begin{array}{c}* \mathrm{~A}, \mathrm{E}, \mathrm{F} \\
8.18 \pm 2.07\end{array}$ & $\begin{array}{c}* \mathrm{~A}, \mathrm{E}, \mathrm{F} \\
5.88 \pm 1.16\end{array}$ & 0.5733 & $p>0.05$ & $\begin{array}{c}* \mathrm{~A}, \mathrm{D}, \mathrm{E}, \mathrm{F} \\
1.09 \pm 0.24\end{array}$ \\
\hline D: Roll mops in souse & $\begin{array}{c}* \mathrm{~A}, \mathrm{E}, \mathrm{F} \\
6.91 \pm 1.09\end{array}$ & $\begin{array}{c}* \mathrm{E}, \mathrm{F} \\
7.61 \pm 3.87\end{array}$ & 0.8174 & $p<0.05$ & $\begin{array}{c}* \mathrm{~A}, \mathrm{~B}, \mathrm{C}, \mathrm{F} \\
1.44 \pm 0.45\end{array}$ \\
\hline E: Herring fillets in aspic & $\begin{array}{c}* \mathrm{~B}, \mathrm{C}, \mathrm{D}, \mathrm{F} \\
13.44 \pm 1.74\end{array}$ & $\begin{array}{c}* \mathrm{~A}, \mathrm{~B}, \mathrm{C}, \mathrm{D}, \mathrm{F} \\
16.48 \pm 4.22\end{array}$ & 0.4923 & $p>0.05$ & $\begin{array}{c}* \mathrm{~A}, \mathrm{~B}, \mathrm{C}, \mathrm{F} \\
1.70 \pm 0.37\end{array}$ \\
\hline $\begin{array}{l}\text { F: Roast herring cuts } \\
\text { in souse }\end{array}$ & $\begin{array}{c}* \mathrm{~B}, \mathrm{C}, \mathrm{D}, \mathrm{E} \\
11.09 \pm 1.75\end{array}$ & $\begin{array}{c}* \mathrm{~A}, \mathrm{~B}, \mathrm{C}, \mathrm{D}, \mathrm{E} \\
1.17 \pm 0.40\end{array}$ & -0.6399 & $p<0.05$ & $\begin{array}{c}* \mathrm{~A}, \mathrm{~B}, \mathrm{C}, \mathrm{D}, \mathrm{E} \\
0.16 \pm 0.08\end{array}$ \\
\hline
\end{tabular}

*Note: significant difference for $p<0.05$ detected

$\mathrm{r}=$ Pearson correlation coefficient from cold and warm marinades

Fat contents in the individual marinades ran from $47 \mathrm{~g} / \mathrm{kg}$ of muscle to $159 \mathrm{~g} / \mathrm{kg}$ of muscle. The highest values $(p<0.05)$ were measured in group $\mathrm{E}$ marinated herrings, the lowest $(p<0.05)$ in groups $\mathrm{B}, \mathrm{C}$, and $\mathrm{D}$.

The TBARS values related to a muscle unit varied between 0.63 and $23.01 \mathrm{mg} \mathrm{MDA} /$ $\mathrm{kg}$, the lowest $(p<0.05)$ being in baked marinades of group $\mathrm{F}$ and the highest $(p<0.05)$ in cooked marinades of group E. No significant differences $(p<0.05)$ among the cold marinades with the exception of products of group A were discovered. TBARS values 
related to a fat unit ranged from $0.64 \mathrm{mmol} \mathrm{MDA} / \mathrm{kg}$ to $3.00 \mathrm{mmol} \mathrm{MDA} / \mathrm{kg}$. Differences between individual types of marinades were the same as during the muscle unit assessment with the exception of the group $\mathrm{D}$ cold marinade the values of which did not differ $(p<0.05)$ from the cooked marinade of group E.

Positive correlation between the tested fat and TBARS in the individual types of marinade was not determined, with the exception of the cold roll mops marinade $(\mathrm{r}=0.8174)$ which differed from the remaining marinades by its short shelf life. Negative correlation was found in the marinade of group $\mathrm{F}$.

\section{Discussion}

Considering the materials and production processes used, marinades represent a rather heterogeneous group of fish products.

In terms of fat stability, the group of cold marinades does not undergo thermal treatment during the production process. Due to these conditions, only unsaturated fatty acids out of all the fatty acids present are liable to non-enzymatic oxidation. Their oxidation intensity depends on the number of double bonds in the molecule. The MUFA content in the muscles of herrings varies from $14 \%$ to $50 \%$ and the PUFA content runs from $33 \%$ to $37 \%$ in accordance with the line, location type and hauling period, nutrition, muscle type and its antioxidant potential (Aidos et al. 2001; Aidos et al. 2002; Aro et al. 2000; Linko et al. 1985). Although the production and storage temperatures do not inactivate the present lipoxygenases, their activity is significantly reduced due to prior quick-freeze storage (Samson and Stodolnik 2001). According to Medina et al. (1999) the lipoxygenases of herrings remain active for about $48 \mathrm{~h}$ during quick-freeze storing. Significant correspondence with these findings can be found in measured TBARS values in cold marinades with oil. In roll mops with significantly the highest TBARS values, tissue contact with oxygen occurs already during their individual selling.

Rolled herring fillets with pepper which showed the lowest TBARS values of all cold marinades contained quite high amounts of black pepper; according to Gulcin (2005) and Nakatani et al. (1986) the antioxidant activity of black pepper is the same as that of industrial synthetic antioxidants. The conducted experiment proved no positive relation of TBARS to fat contents, with the exception of roll mops. Undeland et al. (1998) and Undeland and Lingnert (1999) also arrived at the conclusion that lipid oxidation range in herrings processed in food industry is not dependent upon lipid substrate.

Temperatures declared in technological procedures of warm marinades enhance production not only of unsaturated fatty acids but also saturated fatty acids, resulting in intensification of lipid oxidation and increase the content of primary to tertiary products of their oxidation. Higher TBARS values were also detected by Takaczová (1995) in cooked products. Baked marinades in comparison with the cold ones, showed significantly lowest TBARS values due to the effect of antioxidant action of spices and especially of the Maillard reaction products (Alaiz et al. 1997, Sumay-Martinez et al. 2005) that are formed during the baking process not only form the herring muscle ribose but also from saccharides from flour used for coating the fish raw material during its heat treatment in vegetable oil. The resulting antioxidant effect is enhanced by dilution of malondialdehyde in aqueous phase of the marinade.

TBARS values may be used as an indicator for the assessment of degree of lipid oxidation. The concentration of TBARS in good quality frozen and chilled fish is between 5 and 8 $\mathrm{mg} \mathrm{MDA} / \mathrm{kg}$, where levels of $8 \mathrm{mg} \mathrm{MDA} / \mathrm{kg}$ flesh are generally regarded as the limit of acceptability (Özden and Erkan 2006; Sallam et al. 2007). Maximum TBARS value indicating good quality of marinated fish is so far unknown. Kilinc and Cakli (2005) reported an increase to 9.25 and $9.46 \mathrm{mg} \mathrm{MDA} / \mathrm{kg}$ in pasteurized and non-pasteurized sardine marinades in tomato sauce stored at $4{ }^{\circ} \mathrm{C}$ for 6 months. Özden and Erkan (2006) 
determined after 90 days $9.5 \mathrm{mg} \mathrm{MDA} / \mathrm{kg}$ for rainbow trout marinades in vacuum and $10.26 \mathrm{mg} \mathrm{MDA} / \mathrm{kg}$ in oil packaged samples. However, Sallam et al. (2007) reported only $2.82 \mathrm{mg} \mathrm{MDA} / \mathrm{kg}$ marinated Pacific saury fillets during vacuum packaged storage at $4{ }^{\circ} \mathrm{C}$ for 50-70 days.

Results of determination of secondary products of lipid oxidation by means of fluorimetric micromethod proved lipid oxidation differences among individual cold and warm marinade types caused by antioxidant activity of secondary materials and by different heat treatments of the base material.

In terms of consumer safety it is essential to pay attention to cold marinades in brine sold over the counter and baked marinades in aspic before their expiration date.

\section{TBARS svaloviny sledě obecného (Clupea harengus) v marinádách odebraných z obchodní sítě}

Rybí tuk patř́i mezi významné nutriční složky pro svi̊j vysoký obsah polynenasycených mastných kyselin. Cílem předkládané práce bylo zjistit množství sloučenin reagující s kyselinou 2-thiobarbiturovou u obchodních druhů studených a teplých marinád, obsahujících jako základní surovinu maso sledě obecného (Clupea harengus).

Padesát šest marinovaných rybích výrobků odebraných z obchodní sítě a skladovaných za chladírenských teplot bylo analyzováno před uplynutím doby minimální trvanlivosti.

Nejnižšími hodnotami TBARS se vyznačovaly pečené marinády $(1.17 \pm 0.40 \mathrm{mg} \mathrm{MDA} /$ $\mathrm{kg}$ svaloviny), a ze studených marinád očka s pepřem (5.03 $\pm 0.54 \mathrm{mg} \mathrm{MDA} / \mathrm{kg}$ svaloviny), nejvyšší hodnoty TBARS byly naměřeny u vařených marinád $(16.48 \pm 4.22 \mathrm{mg} \mathrm{MDA} / \mathrm{kg}$ svaloviny) a zavináčů z kusového prodeje (7.61 $\pm 3.87 \mathrm{mg}$ MDA/kg svaloviny). Výsledky ukázaly, že pro tvorbu TBARS u marinovaných sled’ů není obsah tuku vždy rozhodující.

$Z$ hlediska ochrany spotřebitele je nutné před uplynutím doby minimální trvanlivosti věnovat zvýšenou pozornost studeným marinádám v nálevu z kusového prodeje a vařeným marinádám $\mathrm{v}$ rosolu.

\section{Acknowledgement}

This work was supported by the grant of the Ministry of Education, Youth and Sports of the Czech Republic No. MSM 6215712402.

\section{References}

Aidos I, Van Der Padt A, Boom RM, Luten JB 2001: Upgrading of maatjes herring byproducts: production of crude fish oil. J Agric Food Chem 49: 3697-3704

Aidos I, Van Der Padt A, Luten JB, Boom RM 2002: Seasonal changes in crude and lipid composition of herring fillets, byproducts, and respective produced oils. J Agric Food Chem 50: 4589- 4599

Alaiz M, Hidalgo FJ, Zamora R 1997: Antioxidative activity of nonenzymatically browned proteins produced in oxidized lipid /protein reactions. J Agric Food Chem 45: 1365-1369

Aro TL, Tahvonen R, Mattila T, Nurmi J, Sivonen T, Kallio H 2000: Effects of season and processing on oil content and fatty acids of Baltic herring (Clupea harengus membras). J Agric Food Chem 48: 6085-6093

Davídek J. et al. 1981: Laboratorní př́ručka analýzy potravin SNTL/ALFA Praha, 265-266

Decker EA, Warner K, Richards MP, Shahidi F 2005: Measuring antioxidant effectiveness in food. J Agr Food Chem 53: 4303-4310

Esterbauer H 1993: Cytotoxicity and genotoxicity of lipid-oxidation products. Am J Clin Nutr 57 (5Suppl): 779-785

Guillén-Sans R, Guzmán-Chozas M 1998: The thiobarbituric acid (TBA) reaction in foods: A review. Crit Rev Food Sci Nutr 38: 315-330

GULCIN, I 2005: The antioxidant and radical scavenging activities of black pepper (Piper nigrum) seeds. J Agric Food Chem 56: 491-499

Kilinc B, Cakli S 2005: Determination of the shelf life sardine (Sardina pilchardus) marinades in tomato sauce stored at $4{ }^{\circ} \mathrm{C}$. Food Control 16: $639-644$

Linko RR, Kaitaranta JK, Vuorela R 1985: Comparison of the fatty acids in Baltic herring and available plankton feed. Comp Biochem Physiol B 82: 699-705

Medina I, Saeed S, Howell N 1999: Enzymatic oxidative activity in sardine (Sardina pilchardus) and herring (Clupea harengus) during chilling and correlation with quality. Eur Food Res Technol 210: 34-38 
Nakatani N, Inatani R, Ohta H, Nishioka A 1986: Chemical constituents of peppers (Piper spp.) and application to food preservation: naturally occurring antioxidative compounds. Environ Health Perspect 67: 135-142

Özden Ö, Erkan N 2006: Effect of different packing methods on the shelf life of marinated rainbow trout. Archiv für Lebensmottelhygiene 57: 69-75

Sallam KI, Ahmed AM, Elgazzat MM, Eldaly EA 2007: Chemical quality and sensory attributes of marinated Pacific saury (Cololabis saira) during vacuum-packaged storage at $4{ }^{\circ} \mathrm{C}$. Food Chem 102: 1061-1070

Samson E, Stodolnik L 2001: Effect of freezing and salting on the activity of lipoxygenase of the muscle tissue and roe of Baltic herring. Acta Ichtyol Piscat 31: 97-111

Sumay-Martinez MT, Thomas S, Linard B, Binet A, Guerard F 2005: Effect of Maillard reaction conditions on browning and antiradical activity of sugar tuna stomach hydrolysate model system. Food Res Inter 38: 10451050

Takaczová M 1995: Vliv tepelné úpravy na stabilitu lipidů masa. Výživa a potraviny 50: 38-39

Tanizawa H, Sazuka Y, Takino Y 1981: Micro-determination of lipoperoxide in the mouse myocardium by thiobarbituric acid fluorophotometry. Chem Pharm Bull 29: 2910-2914

Undeland I, Ekstrand B, Lingnert H 1998: Lipid oxidation in herring (Clupea harengus) light muscle, dark muscle, and skin, stored separately or as intact fillets. J Amer Oil Chem Soc 75: 581-590

Undeland I, Lingnert H 1999: Lipid oxidation in fillets of herring (Clupea harengus) during frozen storage. Influence of prefreezing storage. J Agric Food Chem 47: 2075-2081 